\title{
Питання психології
}

УДК $355.1(159.9)$

DOI: $10.33099 / 2617-6858-21-59-1-106-113$

Каменюк Ю. В. аспірант Донецького нащіонального університету імені Василя Стуса, Віннищя.

https://orcid.org/0000-0003-1017-1439

\section{РЕЗУЛЬТАТИ ДОСЛІДНО-ЕКСПЕРИМЕНТАЛЬНОЇ РОБОТИ ЩОДО ФОРМУВАННЯ ПАТРІОТИЗМУ ВІЙСЬКОВОСЛУЖБОВЦІВ}

У статті розглядається проблема формування патріотизму у курсантів вищих військових навчальних закладів. Здійснено опис експерименту, що проводився з курсантали Військового інституту Київського Національного університету імені Тараса Шевченка. Подано результати дослідно-експериментальної роботи щодо формування патріотизму військовослужбовиів та наведено їх інтерпретацію.

Ключові слова: патріотизм; дослідно-експериментальна робота; курсант; експеримент; експериментальна група, контрольна група.

Вступ. Проблема патріотизму загострилася після анексії Автономної республіки Крим, тривалого збройного конфлікту на території Донецької та Луганської областей. Відповідно актуалізувалося завдання переосмислення змісту, технології та механізмів формування патріотизму громадян України, в тому числі військовослужбовців.

У статті вирішено наукове завдання щодо формування патріотизму військовослужбовців на прикладі курсантів Військового інституту Київського Національного університету імені Тараса Шевченка.

Нині патріотизм як духовно-моральна цінність, властивість особистості виступає пріоритетним завданням функціонування держави, становлення суспільства, розвитку людини. Джерелом формування патріотизму майбутніх офіцерів, їх професійного та морально-етичного становлення $є$ не тільки суспільно-громадські, а й психологічні механізми. Патріотизм, що формується в особистості курсанта в освітньому процесі, як складний індивідуально-психологічний та соціальний феномен $\epsilon$ тим підгрунтям, тією основою, що забезпечує ефективне i цілеспрямоване формування професійних якостей майбутніх офіцерів. Патріотизм курсанта можна розглядати як систему сформованих у нього соціальнопсихологічних установок, які виражають ставлення курсанта до суспільної вимоги - зі зброєю в руках захищати Батьківщину, готовність його діяти як у свойй майбутній професійній діяльності так і поза іï межами виходячи 3 національних інтересів.
Безперечно ця система соціальних установок $\epsilon$ органічно вплетеною у загальну психологічну структуру особистості майбутнього офіщера, iii систему ціннісних орієнтацій.

Визначені психолого-педагогічні умови склали основу структурно-функціональної моделі формування патріотизму, яка складається 3 таких компонентів: иільового; діагностичного; проектувального; організаиійного; контрольно-оиіночного. Ї̈ виконання полягає в тому, що спочатку проектується програма певних заходів, а ефективність перевіряється в конкретних психолого-педагогічних умовах освітнього процесу вищого військового навчального закладу під час дослідно-експериментальної роботи.

Гіпотеза дослідження грунтується на припущенні, що система формування патріотизму курсантів залежить від:

- з'ясування сутності компонентів, критеріїв та показників за компонентами патріотичного виховання;

- розроблення моделі патріотичного виховання курсантів в освітньому середовищі вищого військового навчального закладу;

- визначення i впровадження ефективних психолого-педагогічних умов формування патріотизму курсантів;

- розроблення i впровадження Цільової програми формування патріотизму військовослужбовців "Патріот України".

Дослідно-експериментальна робота мала на меті оцінку ефективності результатів впровадження розроблених моделі патріотичного виховання курсантів в освітньому середовищі вищого військового навчального закладу та Цільової програми 


\section{Питання психології}

формування

патріотизму

військовослужбовців “Патріот України”.

Розроблена програма передбачала:

1) проведення первинної діагностики курсантів за розробленою методикою формування i оцінки рівня патріотизму курсантів ВВН3;

2) створення експериментальної (ЕГ) i контрольної груп (КГ), оцінку їх однорідності і за необхідності - коригування складу ЕГ і КГ;

3) реалізацію: для ЕГ - проведення заходів за Цільової програмою формування патріотизму військовослужбовців "Патріот України"; для КГ - за встановленою програмою підготовки фахівців відповідно до плану морально-психологічного забезпечення ВВНЗ.

4) підсумкове тестування курсантів після проведення всіх заходів Цільової програми формування патріотизму військовослужбовців "Патріот України";

5) оцінку та інтерпретацію отриманих емпіричних даних в процесі експерименту.

\section{Теоретичне підгрунтя.}

Проведений аналіз наукових досліджень показує, що проблема патріотичного виховання $\epsilon$ предметом розгляду багатьох науковців, які пропонують ряд підходів щодо іiі розв'язання, а саме: історичний, системний, аксіологічний, особистісний, культурологічний.

Проблематика патріотичного виховання різних категорій громадян висвітлена в дослідженнях Б.Ананьєва, I. Беха, Л. Виготського, О. Леонсьєва, С. Максименка, Р. Петронговського, С. Рубінштейна, М. Тимчик, В. Шинкарук та ін.

$$
\text { Деякі аспекти патріотизму }
$$
військовослужбовців стали предметом дослідження В. Алещенка, В. Баранівського, I. Вашкевича, Г. Горського, Л. Кримець, С. Максимова.
Крім того, військово-патріотичне виховання $\epsilon$ складовою національнопатріотичного виховання і регламентується положеннями Стратегії національнопатріотичного виховання, затвердженої Указом Президента України від 18 травня 2019 року № 286/2019 [1].

Незважаючи на значні наукові доробки 3 проблеми патріотичного виховання, на сьогодні немає комплексних досліджень щодо формування патріотизму військовослужбовців 3 урахуванням їх психологічних особливостей.

Зважаючи на актуальність визначеної проблеми, мета статті полягає у висвітленні результатів дослідно-експериментальної роботи щодо формування патріотизму курсантів вищого військового навчального закладу.

Методи дослідження. Дослідноекспериментальна робота проводилася у Військовому інституті Київського Національного університету імені Тараса Шевченка. В експерименті на різних етапах брали участь 246 курсантів Військового інституту Київського національного університету імені Тараса Шевченка другого (98 осіб) та четвертого (148 осіб) курсів, які навчаються за спеціальностями: психологія, політологія, журналістика, зв'язки 3 громадськістю, фінанси та кредит, правознавство, геоінформаційні системи i технології.

Участь курсантів у проведеному експерименті було добровільна і проводилося в умовах повної анонімності.

Для проведення експерименту були створені дві паралелі груп:

- експериментальні - ЕГ-1 (23 чол) і ЕГ2 (24 чол.). чол).

$$
\text { - контрольні - КГ-1 (31 чол) і КГ-2 (11 }
$$

Для проведення експериментальної роботи були обрані актуальні методи дослідження, коротка характеристика яких наведена в табл. 1.

Таблиия 1.

Характеристика основних методів дослідження

\begin{tabular}{|l|l|}
\hline \multicolumn{1}{|c|}{ Метод } & \multicolumn{1}{|c|}{ Коротка характеристика } \\
\hline $\begin{array}{c}\text { Теоретичний } \\
\text { аналіз }\end{array}$ & $\begin{array}{l}\text { Дозволяє проаналізувати стан досліджуваної проблеми і виявити особливості } \\
\text { формування патріотизму у курсантів }\end{array}$ \\
\hline Анкетування & $\begin{array}{l}\text { Застосовувалося для отримання біографічних даних, сформованої патріотичної } \\
\text { спрямованості }\end{array}$ \\
\hline Бесіди & $\begin{array}{l}\text { 3 їх допомогою уточнювалися і доповнювалися дані, отримані іншими } \\
\text { методами }\end{array}$ \\
\hline Опитування & $\begin{array}{l}\text { Дозволяс отримати інформацію соціологічного характеру необхідну для } \\
\text { якісного аналізу досліджуваного контингенту }\end{array}$ \\
\hline
\end{tabular}




\section{Питання психології}

\begin{tabular}{|l|l|}
\hline Спостереження & $\begin{array}{l}\text { Застосовувався для систематичного фіксування і аналізу поведінки і } \\
\text { висловлювань курсантів на тему патріотизму }\end{array}$ \\
\hline Тестування & $\begin{array}{c}\text { Є точним, цілеспрямованим, простим і однаковим для всіх випробовуваних } \\
\text { методом. Проводиться в строго контрольованих умовах і дозволяє об'єктивно } \\
\text { вимірювати досліджувані показники психолого-педагогічного процесу }\end{array}$ \\
\hline $\begin{array}{l}\text { Констатуючий } \\
\text { експеримент }\end{array}$ & $\begin{array}{l}\text { Дозволяє вивчити реальний стан готовності курсантів до дій в екстремальних } \\
\text { ситуаціях. Отримані дані стали вихідними для підготовки і проведення } \\
\text { формуючого експерименту }\end{array}$ \\
\hline $\begin{array}{l}\text { Формуючий } \\
\text { експеримент }\end{array}$ & $\begin{array}{l}\text { Дозволяє конструювати нове психолого-педагогічне явище - підвищити рівень } \\
\text { патріотизму курсантів вузу }\end{array}$ \\
\hline
\end{tabular}

Підсумкові результати емпіричних даних підбивалися, окремо як по кожному показнику i по кожному компоненту патріотичного виховання, так і в цілому

відповідно до оціночної таблиці 2, що говорить про достовірність всебічної математичної перевірки висунутої гіпотези.

\section{Оціночні методики за показниками компонентів ПВ}

\begin{tabular}{|c|c|c|c|c|}
\hline № 3/ח & Компоненти & Показники & Оціночні методики & $\begin{array}{c}\text { Методика оцінки } \\
\text { статистичної } \\
\text { достовірності і } \\
\text { значущості } \\
\end{array}$ \\
\hline \multirow{3}{*}{1.} & \multirow{3}{*}{ Когнітивний } & $\begin{array}{l}\text { Розуміння сутності } \\
\text { патріотизму }\end{array}$ & $\begin{array}{c}\text { Методика } \\
\text { Н.В.Агапової }\end{array}$ & $\begin{array}{l}\text { U-критерій Манна- } \\
\text { Уїтні }\end{array}$ \\
\hline & & $\begin{array}{l}\text { Сформованість } \\
\text { патріотичних } \\
\text { переконань }\end{array}$ & $\begin{array}{c}\text { Методика } \\
\text { М.І.Рожкової }\end{array}$ & $\begin{array}{l}\text { Критерій Фішера, } \\
\text { критерій } \\
\text { Колмогорова- } \\
\text { Смірнова }\end{array}$ \\
\hline & & $\begin{array}{l}\text { Інтерес до вивчення } \\
\text { історії України }\end{array}$ & $\begin{array}{c}\text { Авторське } \\
\text { анкетування } \\
\end{array}$ & $\begin{array}{l}\text { U-критерій Манна- } \\
\text { Уйтні }\end{array}$ \\
\hline \multirow[t]{2}{*}{2.} & \multirow[t]{2}{*}{ Мотиваційний } & $\begin{array}{l}\text { Патріотична } \\
\text { спрямованість: } \\
\text { ціннісна орієнтація } \\
\text { особистості }\end{array}$ & $\begin{array}{c}\text { Методика } \\
\text { М.Рокича та } \\
\text { В.Ядова }\end{array}$ & $\begin{array}{l}\text { Кореляція Спірмена, } \\
\text { Т-критерій } \\
\text { Вілкоксона }\end{array}$ \\
\hline & & $\begin{array}{l}\text { Інтерес до вивчення } \\
\text { історії України }\end{array}$ & $\begin{array}{c}\text { Авторське } \\
\text { анкетування } \\
\end{array}$ & $\begin{array}{l}\text { U-критерій Манна- } \\
\text { Уїтні }\end{array}$ \\
\hline \multirow{3}{*}{3.} & \multirow{3}{*}{ Діяльнісний } & $\begin{array}{l}\text { Активність } \\
\text { патріотичної } \\
\text { діяльності }\end{array}$ & $\begin{array}{c}\text { Методика } \\
\text { Н.В.Агапової }\end{array}$ & $\begin{array}{l}\text { Критерій Стьюдента, } \\
\text { критерій } \\
\text { Колмогорова- } \\
\text { Смірнова }\end{array}$ \\
\hline & & $\begin{array}{l}\text { Інтерес до вивчення } \\
\text { історії України }\end{array}$ & $\begin{array}{c}\text { Авторське } \\
\text { анкетування }\end{array}$ & $\begin{array}{l}\text { U-критерій Манна- } \\
\text { Уїтні }\end{array}$ \\
\hline & & $\begin{array}{l}\text { Військово- } \\
\text { патріотичне } \\
\text { виховання на } \\
\text { бойових традиціях }\end{array}$ & $\begin{array}{c}\text { Методика } \\
\text { С.М.Томіліної }\end{array}$ & $\begin{array}{l}\text { Критерій Стьюдента, } \\
\text { U-критерій Манна- } \\
\text { Уїтні }\end{array}$ \\
\hline
\end{tabular}

Результати і обговорення. Позитивні зміни i їх статистична достовірність за кожним визначеним для цього дослідження показником під час проведення експерименту представлені в таблиці 3

Таблиия 2 
Питання психології

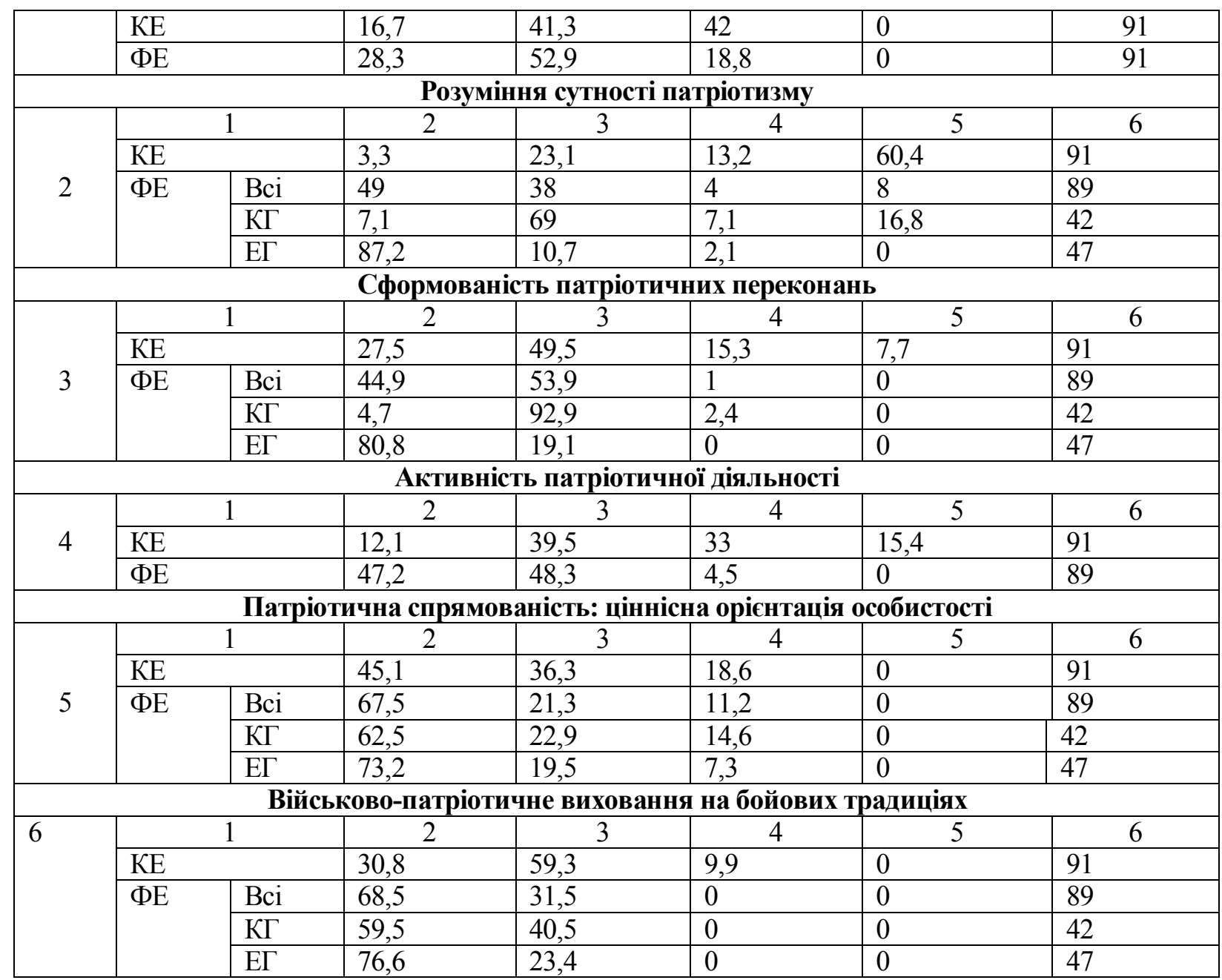

Враховуючи отримані результати та їх респондентів підвищився на формуючому статистичну обробку, можна стверджувати, що рівень сформованості патріотизму у

Таблиия 4

Підсумкові результати респондентів за всіма показниками ПВ на початок і кінець експерименту

\begin{tabular}{|c|c|c|c|c|c|}
\hline \multicolumn{7}{|c|}{ Рівні сформованості патріотизму в\% } \\
\hline Експеримент & високий & середній & низький & нульовий & $\begin{array}{c}\text { Кількість } \\
\text { респондентів }\end{array}$ \\
\hline констатуючий & 20,9 & 37,9 & 24,4 & 16,8 & 229 \\
\hline формуючий & 47,6 & 42,9 & 7,9 & 1,6 & 227 \\
\hline
\end{tabular}

На 26,6\% збільшилася кількість респондентів, які отримали високий рівень сформованості патріотизму. Разом з тим, число респондентів, які займали нульовий рівень зменшилася на 15\% (табл. 5).

Табличя 5

Порівняльні підсумкові результати респондентів КГ і ЕГ за всіма показниками ПВ на формуючому етапі експерименту

\begin{tabular}{|c|c|c|c|c|}
\hline $\begin{array}{c}\text { Рівні } \\
\text { сформованості }\end{array}$ & $\begin{array}{c}\text { Високий рівень } \\
(\%)\end{array}$ & Середній рівень (\%) & Низький рівень (\%) & Нульовий рівень (\%) \\
\hline КГ & 21 & 66,4 & 8,4 & 4,2 \\
\hline ЕГ & 80,6 & 17,1 & 2,3 & 0 \\
\hline
\end{tabular}

Якісні зміни відбулися за рахунок позитивної динаміки в експериментальній групі курсантів після проведення 3 ними заходів Цільової програми формування патріотизму військовослужбовців "Патріот України". Кількість респондентів, які мають 


\section{Питання психології}

високий рівень сформованості патріотизму, в групі, де цілеспрямовано проводилися заходи за авторською програмою, перевищує число респондентів контрольної групи більш ніж на 40\%. Байдужих курсантів до долі
Батьківщини i свого народу в експериментальній групі не виявилося.

Розглянемо результати емпіричних даних диференційовано по кожному ключовому компоненту (табл. 6).

Табличя 6

Підсумкові результати респондентів окремо по кожному компоненту ПВ на початок і кінець експерименту

\begin{tabular}{|c|c|c|c|c|c|c|c|}
\hline \multicolumn{3}{|c|}{$\begin{array}{l}\text { Вид групи та етап } \\
\text { екперименту }\end{array}$} & $\begin{array}{l}\text { Високий } \\
\text { рівень (\%) }\end{array}$ & $\begin{array}{l}\text { Середній } \\
\text { рівень (\%) }\end{array}$ & $\begin{array}{l}\text { Низький } \\
\text { рівень (\%) }\end{array}$ & $\begin{array}{l}\text { Нульовий } \\
\text { рівень (\%) }\end{array}$ & $\begin{array}{l}\text { Кількість } \\
\text { респондентів }\end{array}$ \\
\hline № & & 1 & 2 & 3 & 4 & 5 & 6 \\
\hline \multicolumn{8}{|c|}{ Когнітивний компонент } \\
\hline \multirow{5}{*}{1} & & 1 & 2 & 3 & 4 & 5 & 6 \\
\hline & \multicolumn{2}{|l|}{ KE } & 27,8 & 39,2 & 10,2 & 22,8 & 91 \\
\hline & \multirow[t]{3}{*}{$\Phi \mathrm{\Phi E}$} & Bci & 61,2 & 34 & 2,1 & 0 & 89 \\
\hline & & КГ & 31,1 & 60,2 & 3,2 & 0 & 42 \\
\hline & & $\mathrm{E} \Gamma$ & 88,6 & 10,7 & 0,7 & 0 & 47 \\
\hline \multicolumn{8}{|c|}{ Мотиваційний компонент } \\
\hline \multirow[t]{5}{*}{2} & & 1 & 2 & 3 & 4 & 5 & 6 \\
\hline & KE & & 46,2 & 39,6 & 14,3 & 0 & 91 \\
\hline & $\Phi \mathrm{E}$ & Bci & 68 & 26,4 & 5,6 & 0 & 89 \\
\hline & & КГ & 57,5 & 35,3 & 7,3 & 0 & 42 \\
\hline & & $\mathrm{E} \Gamma$ & 78,1 & 18,3 & 3,7 & 0 & 47 \\
\hline \multicolumn{8}{|c|}{ Діяльнісний компонент } \\
\hline \multirow[t]{5}{*}{3} & & 1 & 2 & 3 & 4 & 5 & 6 \\
\hline & \multicolumn{2}{|l|}{ KE } & 28,6 & 44 & 19,8 & 7,7 & 91 \\
\hline & \multirow[t]{3}{*}{$\Phi \mathrm{E}$} & Bci & 57,9 & 39,9 & 2,3 & 0 & 89 \\
\hline & & КГ & 27,4 & 67,9 & 14,8 & 0 & 42 \\
\hline & & $\mathrm{E} \Gamma$ & 85,2 & 14,8 & 0 & 0 & 47 \\
\hline
\end{tabular}

Рівень показників когнітивного компонента патріотичного виховання курсантів (“Розуміння сутності патріотизму”, “Сформованість патріотичних переконань”, "Інтерес до вивчення історії України”. Блок 1: когнітивний компонент) у всіх групах, які беруть участь у проведеному експерименті, підвищились.

Однак, незважаючи на позитивну динаміку у всіх спостережуваних під час експериментів в групах, найкращий результат також отримано в збірній команді експериментальних груп на формуючому етапі експерименту.

Рівень розуміння сутності патріотизму курсантами експериментальної групи підвищився до 87\%, причому курсантів, які виявили нерозуміння сутності патріотизму під час констатуючого експерименту вдалося звести до $2 \%$, тоді як $24 \%$ ч числа осіб контрольної групи, на жаль, не отримали необхідної інформованості щодо сучасного розуміння патріотизму і самого його змісту і суті.

Отже, в цілому, $87 \%$ респондентів експериментальних груп мають правильне уявлення про сутність патріотизму, виявляють в основному належне, i часом досить стійке ставлення до конституційних і службових обов'язків; і тільки $2 \%$ респондентів показали неглибоке, часткове розуміння сутності патріотизму.

Так 53,9\% від усіх учасників тестування зайняли позицію на середньому рівні сформованості патріотичних переконань, а $44,9 \%$ досягли високого рівня досліджуваного показника когнітивного компонента патріотизму.

Курсанти переконані, що патріотизм можна проявляти $\mathrm{i}$ в мирному житті не тільки беручи участь в мітингах, ходах i патріотичних заходах, а в професійній діяльності.

Частка осіб, які знаходиться на високому рівні сформованості патріотичних переконань, на кінець проведення формуючого експерименту більше, ніж в групі респондентів, які беруть участь в тестуванні під час констатуючого експерименту.

Достовірність і результати третього показника когнітивного компонента ПВ "Інтерес до вивчення історії України" досліджувалася авторським анкетуванням. 


\section{Питання психології}

Відзначимо позитивну динаміку рівнів сформованості цього показника у курсантів, розглядаючи питання анкети по блоку 1.

$68 \%$ респондентів формуючого етапу експерименту досягли високого рівня, 2 1\% - середнього рівня і 11\% - низького рівня сформованості ціннісних орієнтацій особистості. У порівнянні 3 результатами констатуючого етапу експерименту рівень сформованості досліджуваних якостей виріс більш ніж на 20\%. Особливо підкреслимо, що пізнавання, красу природи і екологічну безпеку, а також максимальне повне використання своїх сил, можливостей, здібностей на благо суспільства i Батьківщини 3 усіх цінностей курсанти експериментальної групи на формуючому етапі експерименту знаходять найбільш важливими для свого життя і діяльності.

Розглянутий блок питань авторської анкети дозволив не тільки оцінити рівень знань курсантів, але викликати патріотичні почуття, що розширюють мотиваційне поле курсанта, яке спонукає його до активної діяльності.

Діяльнісний компонент патріотичного виховання розглядався 3 точки зору двох ключових показників: “Активність патріотичної діяльності”, “Інтерес до вивчення історії України" і "Військовопатріотичне виховання на бойових традиціях".

Згідно 3 результатами статистичної обробки даних, отриманих при тестуванні по тесту “Активність патріотичної діяльності” (критерій КолмогороваСмірнова i t-критерію Стьюдента) відмінності між двома розподілами учасників тестування, отримані при формуючому експерименті і констатуючому експерименті достовірні, причому мають позитивну динаміку зростання рівня сформованості активності респондентів в патріотичній діяльності.

Визначення рівня сформованості патріотизму, що реалізуються у вищому військовому навчальному закладі було реалізовано в процесі дослідження думок курсантів 3 питань блоку 3 анкетування "Інтерес до вивчення історії України" показали, що на кінець експерименту курсанти набули впевненості в патріотичній діяльності. У свойй більшості вони висловили думку, що із задоволенням готові самостійно знайомитися з історією України по документам архівів, музеїв та літературних джерел. Беручи участь в заходах 3 патріотичного виховання, курсанти стали сприйнятливі до інформації 3 історії України 3 історичних лекцій, розповідей екскурсоводів 3 демонстрацією документів i експонатів історичних експозицій. Частина курсантів висловили готовність брати активну участь в проведення різних культурно-дозвіллєвих заходів присвячених вивченню та обговоренню історії і бойових традицій.
Отримані
статистичні
дані

підтверджують

підвищення

рівня

сформованості військово-патріотичного виховання курсантів на бойових традиціях, що проявляється в ступені вираженості любові до Батьківщини і бажання слідувати сформованим бойовим традиціям Збройних Сил України. Результати дослідження показують, що обрана технологія, передбачена в авторській моделі патріотичного виховання та Цільовій програмі формування патріотизму "Патріот України", позитивно позначилася на підвищенні високого рівня військовопатріотичного виховання $330,8 \%$ до $68,5 \%$. Курсанти, які оцінюють на констатуючому етапі експерименту свій рівень сформованості військово-патріотичного виховання як низький $(9,9 \%)$, на кінець формуючого експерименту усвідомили свою позицію і підняли свій рейтинг в даному напрямку під час повторного анкетування.

80\% курсантів на кінець проведення формуючого експерименту 3 повною відповідальністю і розумінням висловлювалися про необхідність військовопатріотичного виховання i висловлювали бажання самостійно проводити i організовувати різні заходи, що сприяють військово-патріотичному вдосконаленню підростаючого покоління і однолітків.

Результати формуючого експерименту показали, що цілеспрямована систематична співпраця курсантів і викладачів згідно розробленої моделі патріотичного виховання дозволяе досягти позитивної динаміки у формуванні патріотичної свідомості особистісних переконань, без яких немислиме прийняття духовноморальних цінностей суспільства на основі патріотизму.

Узагальнюючи сказане вище, 


\title{
Питання психології
}

відзначимо, що авторська модель формування та оцінки патріотичного виховання курсантів і авторська анкета цікаві і тим, що дають можливість оцінити рівень формування патріотизму покомпонентно, а це дає, в свою чергу, можливість коректно вибудовувати траєкторію виховного процесу.

Хоча за результатами авторського анкетування мотиваційний компонент домінує над іншими, але за результатами методик відомих вчених когнітивний компонент $є$ головною рушійною силою, яка допомагає усвідомити курсантам те, що відбувається в житті світу і знайти стійку позицію в соціальному житті.

Мотиваційний компонент проявився найбільш виражено після вивчення цільової програми, відвідування заходів патріотичного характеру в навчальному закладі і місті. Так, наприклад, більше $18 \%$ респондентів переосмислили своє ставлення не тільки до бойових традицій, а й усвідомили важливість продовжувати справу по збереженню i примноженню історії, культури, більше 88\% висловили готовність пожертвувати своїм життям заради перемоги над ворогом в разі необхідності.

Рівень сформованості діяльнісного компонента на формуючому етапі експерименту підвищився більш ніж на 10\% за рахунок осмислення курсантами сутності патріотизму, а саме:

- виявлена готовність і здатність до здійснення героїчного вчинку;

- виявлена не тільки готовність відвідувати якомога частіше музеї міста, а й самим провести екскурсію для першокурсників, друзів або за дорученням керівництва інституту.

Висновки: Результати отримані в процесі дослідно-експериментальної роботи дають змогу стверджувати, що гіпотеза дослідження підтверджена: формування патріотизму курсантів буде мати позитивну динаміку, якщо:

- процес формування патріотизму у курсантів розглядається як частина цілісного освітнього процесу, що відбувається у вищому військовому навчальному закладі;

- розроблені концептуальні засади патріотичного виховання курсантів, які передбачають супровід процесу формування особистості громадянина-патріота;

- здійснена опора на системний, діяльнісний, культурологічний, проектувальний і діагностичний підходи до патріотичного виховання курсантів;

- побудована модель патріотичного виховання курсантів;

- визначено критерії та показники сформованості високого рівня патріотизму у курсантів.

Можна стверджувати, що розроблену нову модель патріотичного виховання i коректно скомпоновану комплексну методику оцінки ключових компонентів патріотичного виховання курсантів, можна використовувати як для оцінки патріотичного виховання у вищому військовому навчальному закладі та Збройних Силах України в цілому, так i оцінки рівнів сформованості патріотизму у кожного курсанта.

\section{Список використаних джерел}

1. Стратегія національно-патріотичного виховання. Затверджена Указом Президента України від 18 травня 2019 р. № 286/2019. URL: https://zakon.rada.gov.ua/laws/show/286/2019\#Text.

\section{References}

1. Stratehiia natsionalno-patriotychnoho vykhovannia. [Strategy of national-patriotic education] Zatverdzhena Ukazom Prezydenta Ukrainy vid 18 travnia 2019 r. № 286/2019 URL: https://zakon.rada.gov.ua/laws/show/286/2019\#Text;

\author{
Резюме \\ Каменюк Ю. В. аспирант Донецкого национального \\ университета имени Василия Стуса, Винница. \\ РЕЗУЛЬТАТЫ ОПЫТНО-ЭКСПЕРИМЕНТАЛЬНОЙ РАБОТЫ ПО ФОРМИРОВАНИЮ \\ ПАТРИОТИЗМА ВОЕННОСЛУЖАЩИХ \\ В статье рассматривается проблема формирования патриотизма у курсантов высиих военных \\ учебных заведений. Осуществлено описание эксперимента, который проводился с курсантами \\ Военного института Киевского Национального университета имени Тараса Шевченко.
}




\section{Питання психології}

Представлены результаты опытно-экспериментальной работы по формированию патриотизма военнослужащих и приведены их интерпретацию.

Ключевые слова: патриотизм; опытно-экспериментальная работа; курсант; эксперимент; экспериментальная группа, контрольная группа.

\section{Summary \\ Kamenyuk Yu. V. PhD student of the Donetsk National University named after Vasily Stus, Vinnitsa. \\ RESULTS OF THE EXPERIMENTAL WORK ON FORMING THE PATRIOTISM OF MILITARY SERVICES}

Introduction. The article solves the scientific problem of forming the patriotism of servicemen on the example of cadets of the Military Institute of the Taras Shevchenko National University of Kyiv.

The source of formation of patriotism of future officers, their professional and moral and ethical formation are not only social, but also psychological mechanisms. Patriotism, which is formed in the personality of the cadet in the educational process, as a complex individual psychological and social phenomenon is the basis, the basis that provides effective and purposeful formation of professional qualities of future officers. Undoubtedly, this system of social attitudes is organically woven into the general psychological structure of the future officer's personality, its system of value orientations.

Certain psychological and pedagogical conditions formed the basis of the structural and functional model of patriotism, which consists of the following components: target; diagnostic; design; organizational; control and evaluation. Its implementation is that first a program of certain activities is designed, and the effectiveness is tested in the specific psychological and pedagogical conditions of the educational process of higher military education during research and experimental work.

The experimental work aimed to assess the effectiveness of the implementation of the developed models of patriotic education of cadets in the educational environment of higher military education and the Target Program for the formation of patriotism of servicemen "Patriot of Ukraine".

Purpose. The purpose of the article is to highlight the results of research and experimental work on the formation of patriotism of cadets of higher military education.

Methods. Experimental work was carried out at the Military Institute of the Taras Shevchenko National University of Kyiv. 246 cadets of the Military Institute of the Taras Shevchenko National University of Kyiv took part in the experiment at different stages.

Relevant research methods were chosen for the experimental work: theoretical analysis, questionnaires, interviews, surveys, observations, testing, ascertaining experiment, forming experiment.

The final results of the empirical data were summed up, separately for each indicator and for each component of patriotic education, and as a whole.

Originality. The analysis of scientific research shows that the problem of patriotic education is the subject of many scholars who offer a number of approaches to its solution, namely: historical, systemic, axiological, personal, cultural. Despite significant scientific achievements on the problem of patriotic education, today there is no comprehensive research on the formation of patriotism of servicemen, taking into account their psychological characteristics.

Conclusion. The results obtained in the process of experimental work allow us to state that the research hypothesis has been confirmed. A new model of patriotic education has been developed and a comprehensive methodology for assessing the key components of patriotic education of cadets has been correctly composed, which can be used to assess patriotic education in higher military education and the Armed Forces of Ukraine as a whole.

Key words: patriotism; research and experimental work; cadet; experiment; experimental group, control group.

Recelved/Поступила: 26.02. 21. 